\title{
Core policies disparity response to COVID-19 among BRICS countries
}

\author{
Jun Jiao ${ }^{1}$, Leiyu Shi², Yuyao Zhang ${ }^{1}$, Haiqian Chen ${ }^{1}$, Xiaohan Wang ${ }^{1}$, Manfei Yang ${ }^{1}$, Junyan Yang ${ }^{1}$, \\ Meiheng Liu ${ }^{1}$ and Gang Sun ${ }^{1,2^{*}}$ (1)
}

\begin{abstract}
Objective: To provide experience for formulating prevention and control policies, this study analyzed the effectiveness of the Coronavirus disease 2019(COVID-19) prevention and control policies, and evaluated health equity and epidemic cooperation among BRICS countries.

Methods: This study summarized the pandemic prevention and control policies in BRICS countries and evaluated the effectiveness of those policies by extracting COVID-19 related data from official websites.

Result: As of May 4, 2021, responding to COVID-19. China adopted containment strategies. China's total confirmed cases $(102,560)$ were stable, without a second pandemic peak, and the total deaths per million (3.37) were much lower than others. India and South Africa who adopted intermediate strategies have similar pandemic curves, total confirmed cases in India $(20,664,979)$ surpassed South Africa $(1,586,148)$ as the highest in five countries, but total deaths per million (163.90) lower than South Africa (919.11). Brazil and Russia adopted mitigation strategies. Total confirmed cases in Brazil $(14,856,888)$ and Russia $(4,784,497)$ continued to increase, and Brazil's total deaths per million $(1,936.34)$ is higher than Russia (751.50) and other countries.

Conclusion: This study shows BRICS countries implemented different epidemic interventions. Containment strategy is more effective than intermediate strategy and mitigation strategy in limiting the spread of COVID-19. Especially when a strict containment strategy is implemented in an early stage, but premature relaxation of restrictions may lead to rebounding. It is a good choice to combat COVID-19 by improving the inclusiveness of intervention policies, deepening BRICS epidemic cooperation, and increasing health equities.
\end{abstract}

Keywords: COVID-19, BRICS health equity, National response, Core strategy comparison

\section{Introduction}

In Dec 2019, the first Viral Pneumonia of Unknown Cause was reported in Wuhan, Hubei province, China [1]. The pandemic rapidly spread worldwide, on Jan 30, 2020, the World Health Organization (WHO) declared the Coronavirus disease 2019(COVID-19) outbreak a public health emergency of international concern [2]. Based on national health care system, population structure, and

\footnotetext{
*Correspondence: sunhoney163@163.com; gsun15@jhu.edu

${ }^{1}$ Department of Health Management, School of Health Management, Southern Medical University, Guangzhou, Guangdong 510515, P.R. China

Full list of author information is available at the end of the article
}

epidemic situations, countries have taken different interventions, including restrictive measures, border prevention and control measures, health protection measures, and key population control measures. Countries are also trying to achieve herd immunity through vaccines. USA, Russia and China successfully developed vaccines and carried out mass vaccination. However, due to the limitations of research, immunization duration, and other factors, it needs a long time to achieve herd immunity [3]. Furthermore, there were 3,815 coronavirus genotypes [4], and coronavirus variants are still increasing [5]. In this case, social intervention policies remain necessary to combat COVID-19. original author(s) and the source, provide a link to the Creative Commons licence, and indicate if changes were made. The images or other third party material in this article are included in the article's Creative Commons licence, unless indicated otherwise in a credit line to the material. If material is not included in the article's Creative Commons licence and your intended use is not permitted by statutory regulation or exceeds the permitted use, you will need to obtain permission directly from the copyright holder. To view a copy of this licence, visit http://creativecommons.org/licenses/by/4.0/. The Creative Commons Public Domain Dedication waiver (http://creativeco mmons.org/publicdomain/zero/1.0/) applies to the data made available in this article, unless otherwise stated in a credit line to the data. 
With the deepening globalization, on Mar 11, 2020, WHO Director-General, Dr. Tedros declared COVID-19 was a global pandemic [6], which needs the world to work together. However, vaccine nationalism, racial discrimination, health resources differences, inadequate primary health care system, and barriers of health products trade hampered health equity and COVID-19 improvement. In this study, we choose BRICS countries as our study subjects, which are made up of five major emerging countries with global influence [7], including Brazil, Russia, India, China, and South Africa. Their whole population is more than 3 billion. Their policies and effectiveness have influenced world COVID-19 pandemic. Responding to COVID-19, developed countries failed to play a leading role, nor can lead the global economic recovery [8]. Since established, BRICS countries have been carrying out public health cooperation and making efforts for health equity.

Containment and mitigation strategies, as guiding strategies for different phases of influenza pandemics, were first proposed in the WHO Global Influenza Preparedness Plan in 2005 [9]. Containment strategy aims to prevent spread of infection in defined areas [10], which prefers social intervention measures to rapidly block spread of epidemics in an early stage [11]. In fact, main points of containment strategy were reflected in SASR 2004 prevention and control measures, and were more fully implemented in H1NI 2009 prevention and control measures. Some scholars suggest that measures based on isolation are the fundamental anti-pandemic measures [12]. However, some scholars believe that it is difficult to implement, especially at the epidemic peak to track cases [13]. In COVID-19, scholars generally believe that containment strategy can help control spread and reduce mortality [14], and key measures including lockdown, isolation and tracing of close contacts play an important role [15-17]. However there are different opinions about stages and scope of containment strategy, Hyunjin Son and Silvia Caristia respectively believe that containment strategy is more suitable in limit scopes and early pandemic stages $[18,19]$. Mitigation strategy is recommended for actions in phase 5 and 6 of pandemic, essentially reducing the pandemic impact [10]. Intermediate strategy came into being in the discussion of implementation stage of containment and mitigation strategy. Proponents of an intermediate strategy believe that containment and mitigation strategy should be taken at different epidemic stages. However, they have different opinions on the timing of changing the response strategy. Factors including clinical and epidemiological characteristics of a new virus and the impact of control measures early a pandemic should be analyzed in real time [20-22]. Mathias Peirlinck proposed to shift to mitigation strategy induced by behavior changes when asymptomatic carriers become at high risk [23]. Mitigation strategy supporters based on conditions that it is almost impossible to fully manage infection source because of incubation period and the asymptomatic. In that way, epidemic can't be blocked. It should be allowed to spread in a manageable way until forms an immune barrier. Krishna Regmi supported mitigation strategy might be the way forward and more acceptable [24]. Benjamin J Cowling believed social distancing has a less disruptive social and economic impact than complete lockdown, and also can meaningfully control COVID-19 with a wider range of application [25].

With COVID-19 spread, there were differences in response policies and effectiveness among BRICS countries. We studied COVID-19 epidemic prevention and control policies among BRICS countries, including China adhered to containment strategy, which focusing on the whole transmission process. India and South Africa adopted intermediate strategies that took different strategies at different epidemic stages. Brazil and Russia took mild mitigation strategies to ease pressure on health care systems. To provide experience for formulating prevention and control policies, improving health equity among BRICS countries and carrying out international epidemic cooperation, this study analyzed the effectiveness of COVID-19 prevention and control policies and evaluated health equity and epidemic cooperation among BRICS countries.

\section{Methods}

COVID-19 data of this study (total confirmed cases, daily new cases, total deaths) were extracted from official websites, which included COVID-19 daily updates from the National Health Commission, PRC, Johns Hopkins University \& Medicine Coronavirus Resource Center and, WHO. COVID-19 pandemic prevention and control policies of BRICS countries were collected from BRICS government web pages, WHO website, and the University of Washington COVID-19 policy information website. Then chronological sorted to form COVID-19 pandemic data chart and time axis of national responses.

\section{Result \\ National response to the COVID-19 pandemic Containment strategy of China}

In Dec 2019, China reported COVID-19. After COVID19 began to spread, China took measures, including lockdown Wuhan city, closing the passage, and asking citizens to quarantine at home on Jan 23, 2020. Public health measures were launched nationwide to manage "four categories of people (confirmed cases, suspected cases, febrile patients who might be carriers, and close 
contacts)", follow the "four early" principle, and block transmission route. To guarantee treatment and reduce deaths, government finance covered all costs of COVID19 treatment. Furthermore, government coordinated national manpower, medical equipment, and materials to support Hubei Province, quickly built 16 mobile cabin hospitals, and organized the province-city medical pairing support relationship. On May 8, 2020, China's epidemic work moved from emergency status to normalization. Prevention and control policy shifted to import cases prevention, sporadic cases containment, epidemic normalization prevention, and promotion of scientific and technological breakthroughs in vaccines and drugs.
Table 1 summarizes the main containment measures in China.

\section{Intermediate strategy of India and South Africa}

On Jan 30, 2020, India reports the first confirmed case. Before that, India implemented immigration control measures to block import cases, and restricted medical supplies and medicines export to ensure domestic needs. From Mar 25 to June 30, 2020, India entered a five-phase "lockdown" with regional management. Then, India began to stage unseal, enterprises gradually reopened. On Sep 1, 2020, India became the world's fastest country of daily new cases, then some cities restarted public

Table 1 The three-stage major measures taken for COVID-19 in China

\begin{tabular}{|c|c|}
\hline Stage & Measures \\
\hline Stage 1: Initial stage of COVID-19 & $\begin{array}{l}1 \text { Classification of infectious diseases: the COVID-19 included in category B infectious diseases, and } \\
\text { adopted prevention and control measures for Category A infectious diseases. } \\
2 \text { Established COVID-19 Command System: } \\
\text { (1) The National Health Commission made arrangements to send expert teams to Wuhan to conduct } \\
\text { on-site investigations. } \\
\text { (2) The central government set up a leading group on the disease response. }\end{array}$ \\
\hline Stage 2: spreading stage of COVID-19 & $\begin{array}{l}1 \text { Lockdown Wuhan city: } \\
\text { (1) Activated public health emergency II level responses of Hubei province. } \\
\text { (2) On Jan 23, 2020: temporarily closed Wuhan outbound routes of airports and railway stations at } 10 \\
\text { a.m.; Suspended city's passenger transport operations; People were told to cannot leave Wuhan and } \\
\text { home quarantine; Lockdown Wuhan city lasted } 76 \text { days. } \\
2 \text { Community and social control measures: } \\
\text { (1) All provinces activated Level } 1 \text { public health emergency response. } \\
\text { (2) Adopt measures to put "four categories of people" under classified management and conducted } \\
\text { mass screenings to search for them; All those in need are tested, isolated, hospitalized, or treated was } \\
\text { implemented. } \\
\text { (3) Strictly observed the principle of early detection, reporting, quarantine, and treatment. } \\
\text { (4) Extended the Chinese New Year holiday of } 2020 \text { and postponed the opening of schools. } \\
\text { (5) Required residents to implement home quarantine, 14-day isolation after trans-regional travel, and } \\
\text { protective measures including wearing masks, maintaining social distance and reducing gatherings. } \\
3 \text { Medical treatment policy: } \\
\text { (1) Medical expenses incurred by COVID-19 patients will be covered by basic medical insurance, } \\
\text { critical illness insurance and medical assistance, and the individual portion will be subsidized by the } \\
\text { government. Medical insurance has also reduced the cost of treatment for suspected patients. } \\
\text { (2) Established a mechanism to organize pairing assistance from other provinces to Hubei's cities for } \\
\text { treatment; Nationwide resources were mobilized to assist Hubei province; Rapidly constructed } 16 \\
\text { mobile cabin hospitals by mobilizing nationwide medical equipment. } \\
\text { (3) Produced and released Diagnosis and Treatment Protocol for Novel Coronavirus Pneumonia, } \\
\text { which adding methods of traditional Chinese medicine. }\end{array}$ \\
\hline
\end{tabular}

Stage 3: normalize prevention and control stage 1 Guard against imported cases:

(1) Tighten up border management, implemented "the first point of entry management" and nucleic acid testing of inbound personnel.

(2) Implemented the declaration of health information for inbound personnel, and suspended the entry of foreigners holding Chinese visas and residence permits.

2 Prevent a rebound in indigenous cases:

(1) Adopted precise and differentiated epidemic control strategies: Low-risk regions should focus on imported cases and restore production and life at an appropriate time; Medium-risk regions should prevent both imported cases and indigenous spread; High-risk regions should strictly commit epidemic prevention and control.

(2) Using health color code as identification and the evidence of daily life and access to public places. (3) For sporadic cases: Strengthen screening of close contacts; Trace source of confirmed cases; Strengthen early-warning research and risk grading; Strengthen quarantine control of key personnel. 3 Expedited vaccines and medicines research and application:

(1) COVID-19 therapeutic drugs were included in new scope of medical insurance list.

(2) In Dec, launched a key population vaccination campaign. 
health measures. In Feb 2021, India relaxed social control, held traditional cultural festivals, and almost completely abandoned social distance policies.

South Africa is far away from the Eurasian continent. Until Mar 5, 2020, South Africa reported the first case imported from Italy. Then government began to take measures, such as closing borders and ports, strengthening epidemic surveillance. Midnight on Mar 26, 2020, South Africa began a 21-day lockdown as the strictest Level 5. On April 23, 2020, government gradually reduced blockade levels, relaxed community control measures, implemented "risk adjustment strategy", and carried out an economic policy of resuming work and production. When COVID-19 epidemic rebounded with a second outbreak, border control, social prevention and control measures such as curfews and masks were reintroduced, but the country's block level was not changed. In contrast to other countries' eagerness to vaccine, South Africa moved slowly, opened vaccination registry on April 16, 2021. Table 2 summarizes the main epidemic control measures in India and South Africa that combine containment and mitigation policies.

\section{Mitigation strategy of Brazil and Russia}

In the early stage, Brazilian people and government did not pay attention and only regarded COVID-19 as ordinary flu. In Jan 2020, after receiving reports of COVID-19 suspected cases, Brazil initiated a public health emergency and joint multi-sectoral epidemic prevention team. In the face of the federal government's lag action, Brazilian states gradually issued epidemic decrees. Many states restricted the flow of people by lockdown city, quarantine measures, and keeping social distance. In June 2020, as many places started economic recovery plans and relaxed quarantine policies, the epidemic worsened in some cities after "being unsealed with epidemic". Some regions have upgraded prevention and control measures to slow down the COVID-19 outbreak, and vaccination starting on Jan 28, 2021.

On Jan 31, 2020, Russia firstly found two confirmed cases, and government immediately took a series of measures to severely seal border and restrict flow between Chinese and Russian. However, due to Russia's weak control of immigrants from Europe and North America, and a policy gap, many people from affected areas flowed into Russia. In May 2020, clustering infections were reported in medical institutions and military. In that case, Russian government still implemented a national economic recovery plan. On May 11, 2020, the Russian President announced the end of paid holidays and entered a new stage of fighting COVID-19. Later, prevention and control restrictions were gradually lifted. When the second epidemic began in Oct 2020, states have restarted prevention and control measures, such as restricting gathering, wearing masks, reopening health centers that had been closed in July 2020. Table 3 summarizes the main mitigation measures in Brazil and Russia.

\section{Epidemic cooperation in BRICS}

BRICS countries have actively engaged in COVID-19 cooperation and reached consensus through bilateral and BRICS Summit. Firstly, health cooperation: sent medical experts, provided medical supplies, established an early warning mechanism for infectious diseases, and sharing experience in fighting COVID-19; Secondly, vaccine cooperation: carried out vaccine clinical testing, production, and supply cooperation, established vaccine research and development center; Thirdly, economic cooperation: The New Development Bank granted \$1 billion in emergency loans to each BRICS member countries for purchasing of personal protective equipment and easing the economic recession. Table 4 summarizes cooperation measures among BRICS countries.

\section{Results of the prevention and control measures of COVID-19 in BRICS countries Results of the prevention and control measures in China}

Since the end of Jan 2020, China's daily new cases have sharply increased and government launched a series of containment measures. On Feb 12, 2020, to revise diagnosis results, Hubei Province investigated previously suspected cases adding clinical diagnosis as the basis. After that, daily new cases reached a peak and then declined. On Mar 19, 2020, it was the first time reported no local cases. On April 8, 2020, Wuhan lockdown lifted, and epidemic improved. On May 8, 2020, local cases were stable, and China's epidemic work shifted to preventing inbound cases and domestic resurgence [26]. During the normalization stage, there have been several sporadic domestic cases and local outbreaks, without a second epidemic wave. As shown in Fig. 1.

\section{Results of the prevention and control measures in India and South Africa}

India and South Africa have a very similar epidemic curve with a trough between two distinct peaks. On Jan 25, 2020, India implemented immigration control measures, kept daily new cases zero in the early period. By Mar 4, 2020, India's confirmed cases had sharply risen after 15 Italian tourists were diagnosed. On Mar 25,2020 , India entered a five-stage blockade, with a slowly daily new cases increase and no spike. With "unsealed" policy began in June 2020, and enterprises gradually resumed work, the first wave began to climb, and peaked in Sep 2020. Then, infections declined slowly. By Feb 2021, daily new cases dropped below 


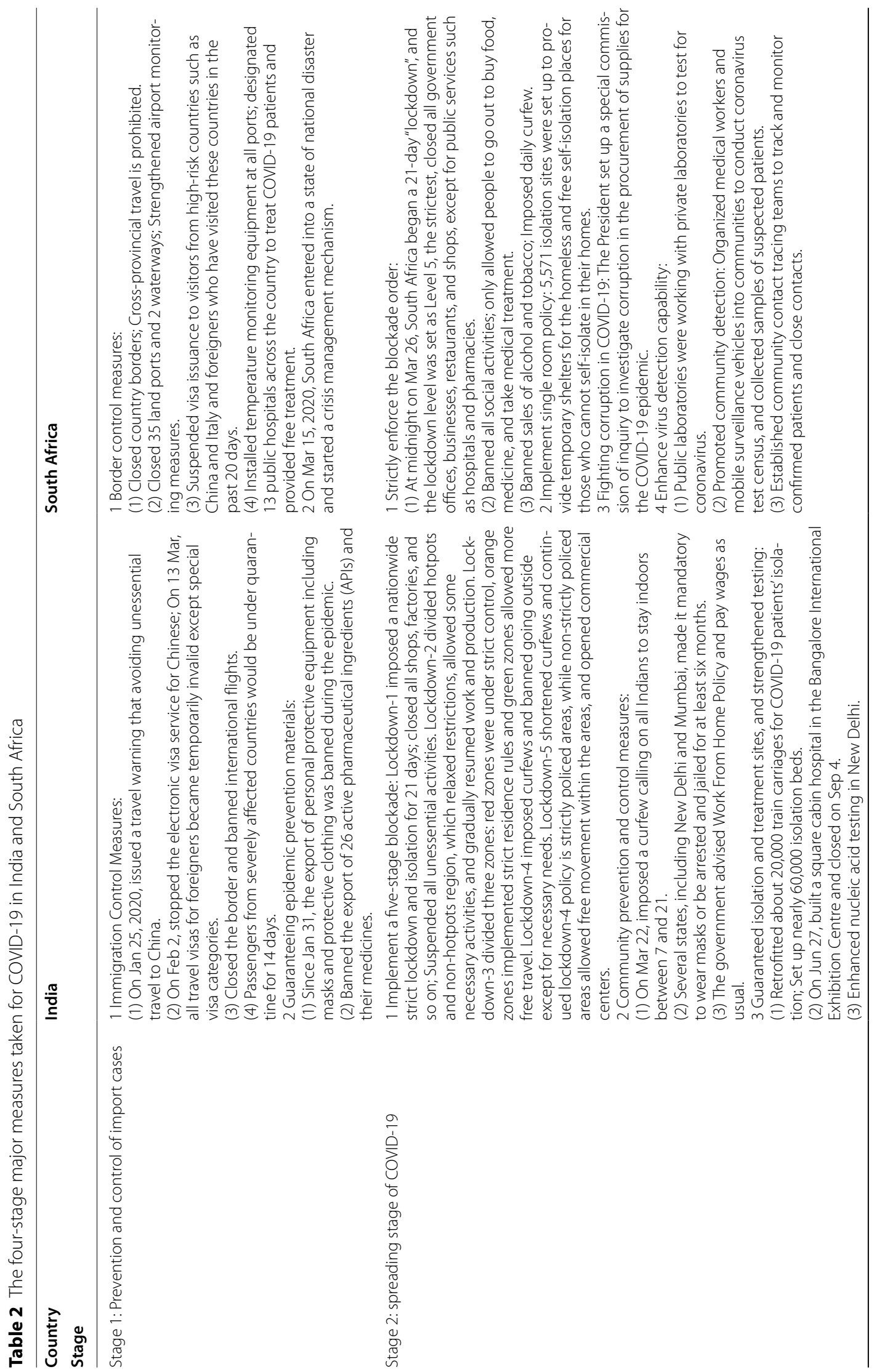




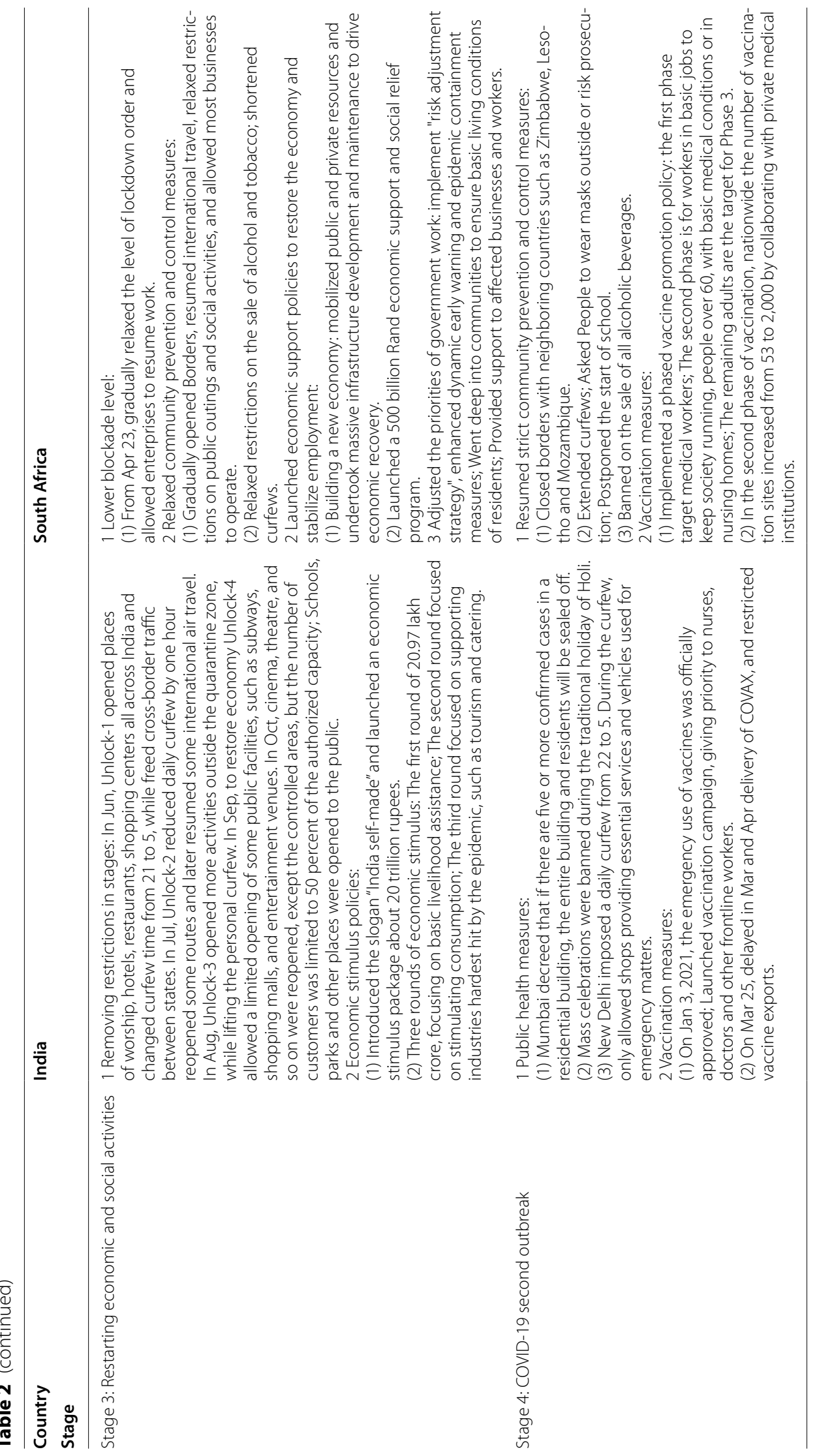




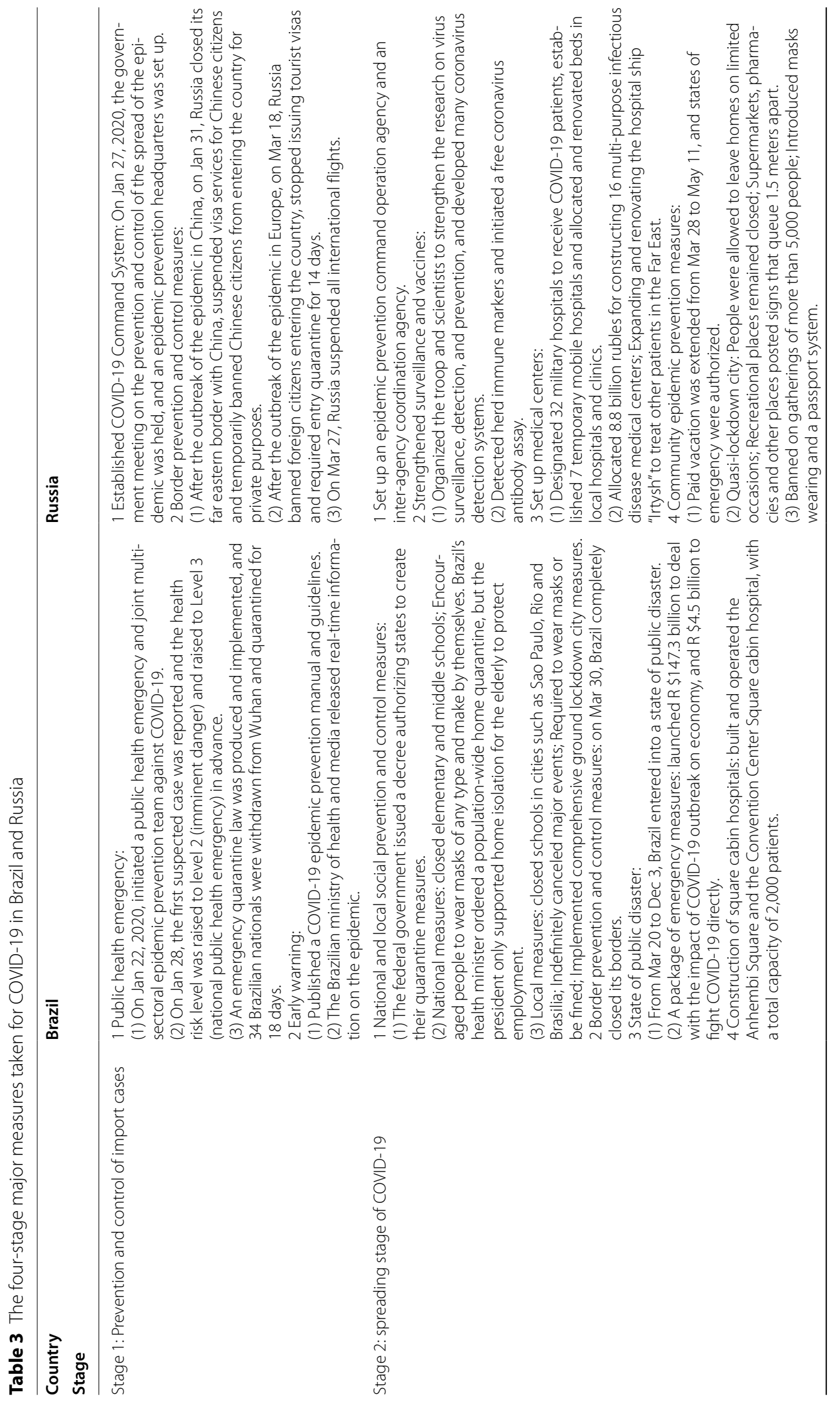




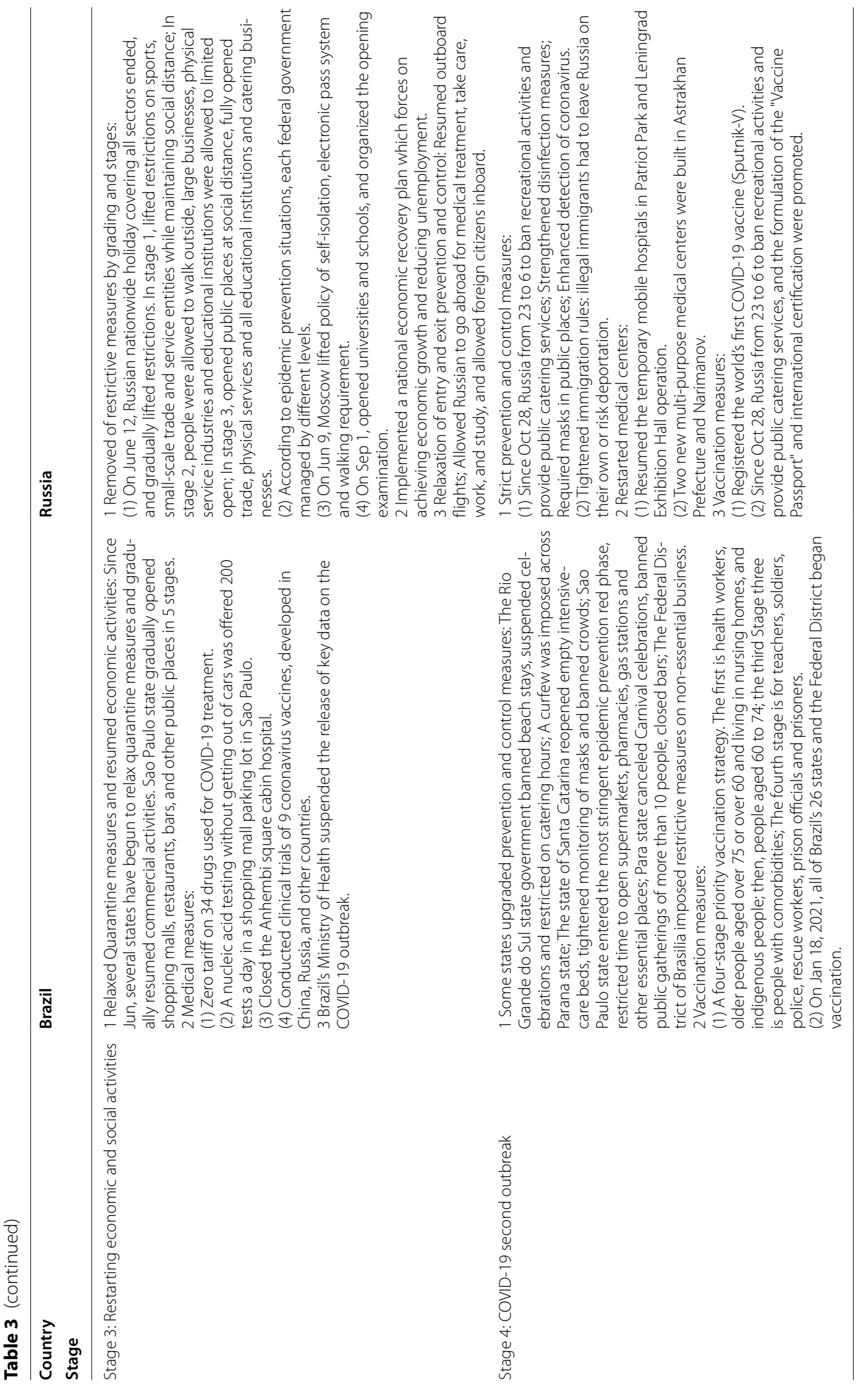


Table 4 Cooperation measures taken for COVID-19 among BRICS countries

\begin{tabular}{|c|c|}
\hline Measures & Key elements \\
\hline peration & $\begin{array}{l}1 \text { Sent medical experts: } \\
\text { (1) On Feb 5, 2020, seven Russian epidemiologists arrived in Beijing to help China contain the spread of the virus and develop } \\
\text { a vaccine. } \\
\text { (2) On April 11, China sent a 10-member expert team to Russia to exchange experience and provide guidance and training on } \\
\text { prevention and control, diagnosis, and treatment. } \\
2 \text { Provided medical supplies: } \\
\text { (1) In Feb 2020, Russia, India and South Africa donated masks and other medical supplies to China. The Brazil-China Association } \\
\text { for the Promotion of Peaceful Reunification donated to China. } \\
\text { (2) Since March, China has donated personal protective equipment, nucleic acid extraction reagents and other materials in } \\
\text { batches to Russia, India, Brazil and South Africa. } \\
\text { (3) On April 17, India committed to delivering nearly } 100 \text { million Hydroxychloroquine tablets to Russia for the treatment of } \\
\text { COVID-19. } \\
\text { (4) On May 23, Russia delivered the Coronavirus diagnostic test system to South Africa. } \\
3 \text { Established an early warning mechanism for infectious diseases: } \\
\text { (1) On April 28, 2020, heads of BRICS Foreign Ministries held a special meeting on COVID-19 to support the joint establishment } \\
\text { of an early warning mechanism for infectious diseases. } \\
\text { (2) On Sep 9, 2021, the New Delhi Declaration of the } 13 \text { th BRICS Summit endorsed the progress made in establishing an early } \\
\text { warning system for the prevention of large-scale infectious diseases in BRICS countries to identify and predict future pandem- } \\
\text { ics through institutional cooperation. } \\
4 \text { Shared experiences in fighting COVID-19: } \\
\text { (1) China, South Africa, Russia, and Brazil held video conferences for COVID-19 prevention and control. } \\
\text { (2) Experts in the design of Leishenshan Hospital in China, shared construction experience and helped South Africa improve } \\
\text { the construction plan of anti-epidemic hospitals. } \\
\text { (3) From March to April 2021, the National School of Governance of China offered courses on national governance and emer- } \\
\text { gency management for middle and senior leaders of South African public organizations. }\end{array}$ \\
\hline Vace & $\begin{array}{l}\text { (1) China and Russia are working together to develop and produce COVID-19 vaccines; Russia and Brazil carry vaccine coopera- } \\
\text { tion in three aspects: clinical testing, vaccine production, supply to Brazil and the whole Latin American market; The Russian } \\
\text { vaccine "SputnikV" manufactured in India, Brazil, and China. } \\
\text { (2) On July 24, 2020, Brazil launched a clinical trial of a coronavirus vaccine from China, which vaccinated 9,000 volunteers } \\
\text { within } 90 \text { days. } \\
\text { (3) On Nov 17, 2020, according to the Moscow Declaration of the 12th BRICS Summit, we will work to ensure that vaccines, } \\
\text { once available, are distributed in a fair, equitable, and affordable manner; We also encourage the BRICS Vaccine Research and } \\
\text { Development Center to become operational as soon as possible. } \\
\text { (4) The contribution made by BRICS countries in providing over a billion COVID-19 vaccine doses, including grants and dona- } \\
\text { tions, bilaterally, to international organizations and the COVID-19Vaccines Global Access (COVAX) facility. }\end{array}$ \\
\hline Economic cooperation & $\begin{array}{l}\text { (1) In April 2020, New Development Bank established an emergency assistance facility, including US } \$ 5 \text { billion for health and } \\
\text { social security expenditures and US } \$ 5 \text { billion to support economic recovery of member countries. } \\
\text { (2) New Development Bank has issued three COVID-19 preparedness bonds and } \$ 1 \text { billion in emergency loans to five member } \\
\text { countries to purchase hospital beds, ventilators, and protective equipment for frontline medical workers, as well as to mitigate } \\
\text { the economic downturn caused by the pandemic and lockdown. }\end{array}$ \\
\hline
\end{tabular}

20,000. But in early Mar 2021, the outbreak worsened with a slow confirmed case increase. Then COVID-19 explosion with economic activities restarted and population management relaxed. On April 11 2021, India became the world's second-highest number of COVID19 cases. As shown in Fig. 2.

Since the first imported case from Italy was reported on Mar 5, 2020, daily new cases in South Africa have been slowly increasing. During a 21-day lockdown, daily new cases slowed down to within 100 cases. Since April 23,2020 , with the gradual easing of lockdown, daily new cases have re-increased and reached the peak of the first wave. The government restarted public health and social control measures, then the first wave gradually fell back. Affected by the mutant coronavirus 501Y.v2 [27], daily new cases re-increased in Nov 2020, reached the peak of the second wave in Jan 2021, then fell back rapidly. After the second wave outbreak, daily new cases had stabilized about 1,000 in May 2021. As shown in Fig. 3.

\section{Results of the prevention and control measures in Brazil and Russia}

The trend of the epidemic curve in Brazil and Russia were similar, with two obvious epidemic peaks. Unlike India and South Africa, there was no effective drop between the two epidemic peaks, that is, after an epidemic peak, daily new cases were still higher than the previous one. Brazil confirmed its first case on Feb 26, 2020. More than half a month, confirmed cases slowly increased. When the first death was reported on Mar 17, 2020, COVID19 in Brazil had gradually spread, and by Mar 20, 2020, whole country had entered a state of public disaster. On April 5, 2020, total confirmed cases in Brazil exceeded 10,000 , making it the worst-affected country in South America. From early Mar to May 2020, when Brazil's 


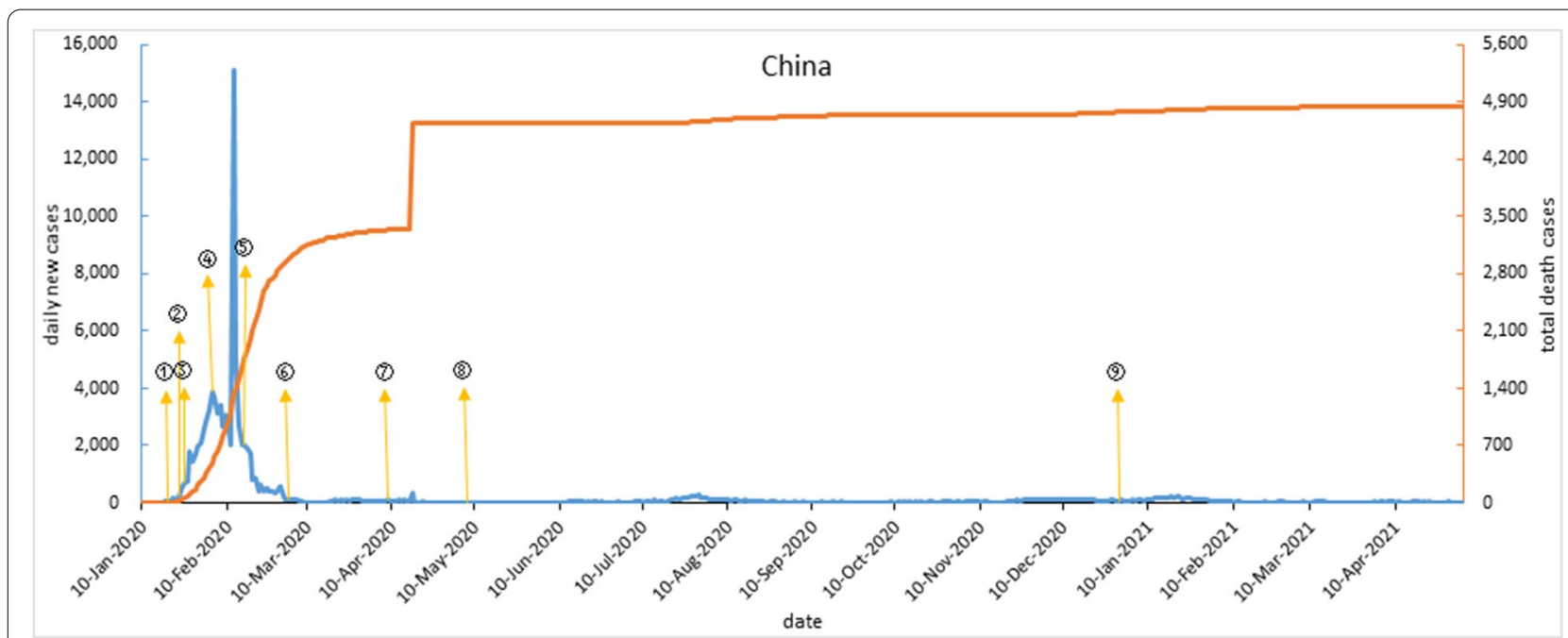

Fig. 1 COVID-19 outbreak curve and timeline of implementation of major interventions in China. Note: (1) On Jan 20, 2020, COVID-19 was included as a national class B infectious disease. (2) At 10 o 'clock on Jan 23, lockdown Wuhan city and required all citizens to wear masks. (3) On Jan 25, all provinces with confirmed cases of COVID-19 launched a public health emergency response of level I. (4) On Feb 4, the Huoshen Mountain cabin hospital began to receive patients, organized pairing assistance from other provinces to cities in Hubei for treatment. (5) On Feb 16, all communities in Hubei Province implemented strict blockade management for 24 hours and launched a large-scale community screening. (6) On March 3, the COVID-19 diagnosis and treatment plan (trial seventh edition) was issued. (7) On April 8, Wuhan was unsealed. (8) On May 8, China's epidemic work moved from emergency status to normalization. (9) On Dec 31, COVID-19 vaccine was launched in China

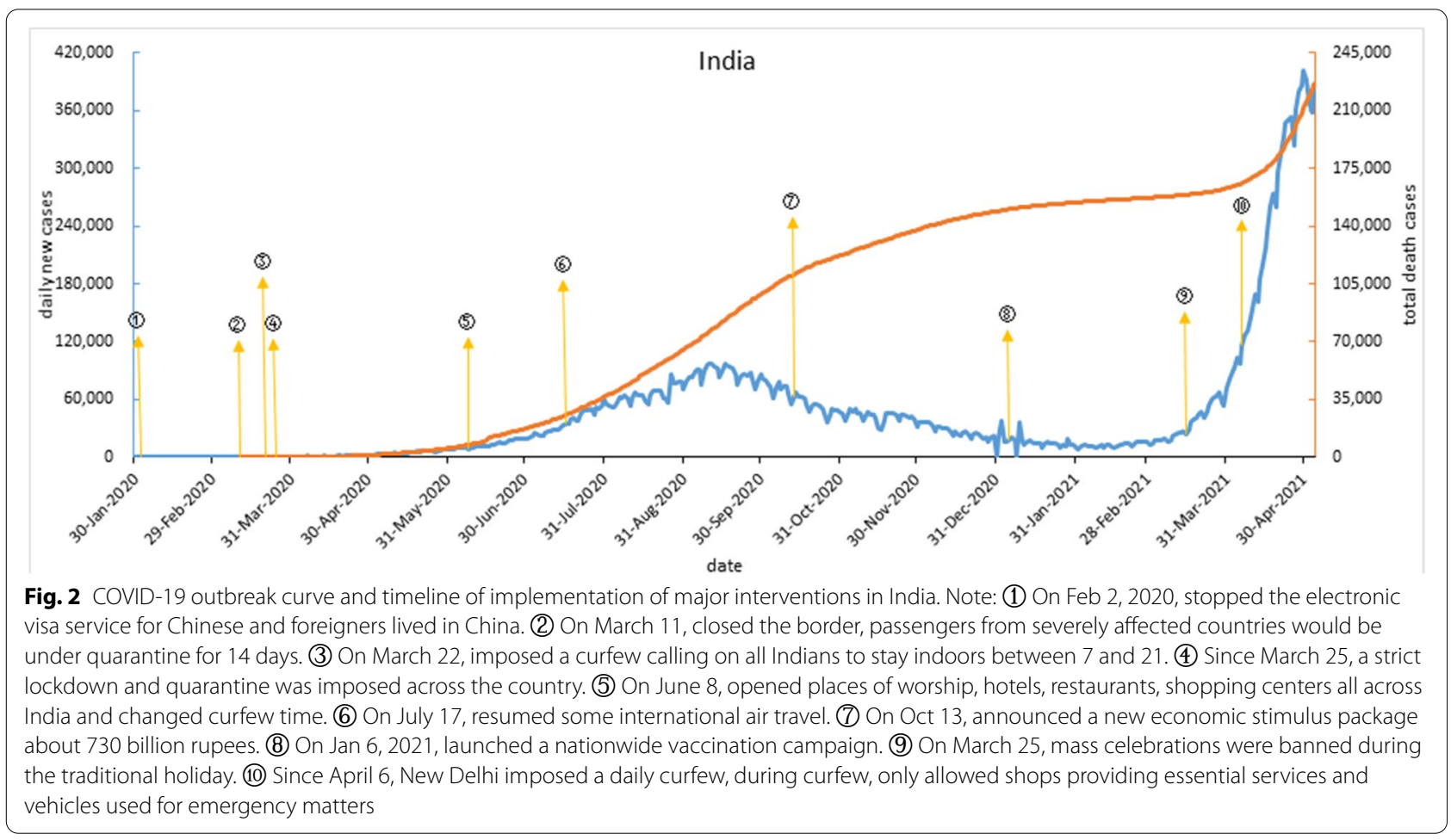

federal and local governments responded to COVID19 with different strategies, infection was spreading. Since the beginning of June 2020, the epidemic has been

gradually unsealed and economy has resumed, but the epidemic has worsened. And the second wave began in Nov 2020. In addition, daily new cases curve in Brazil 


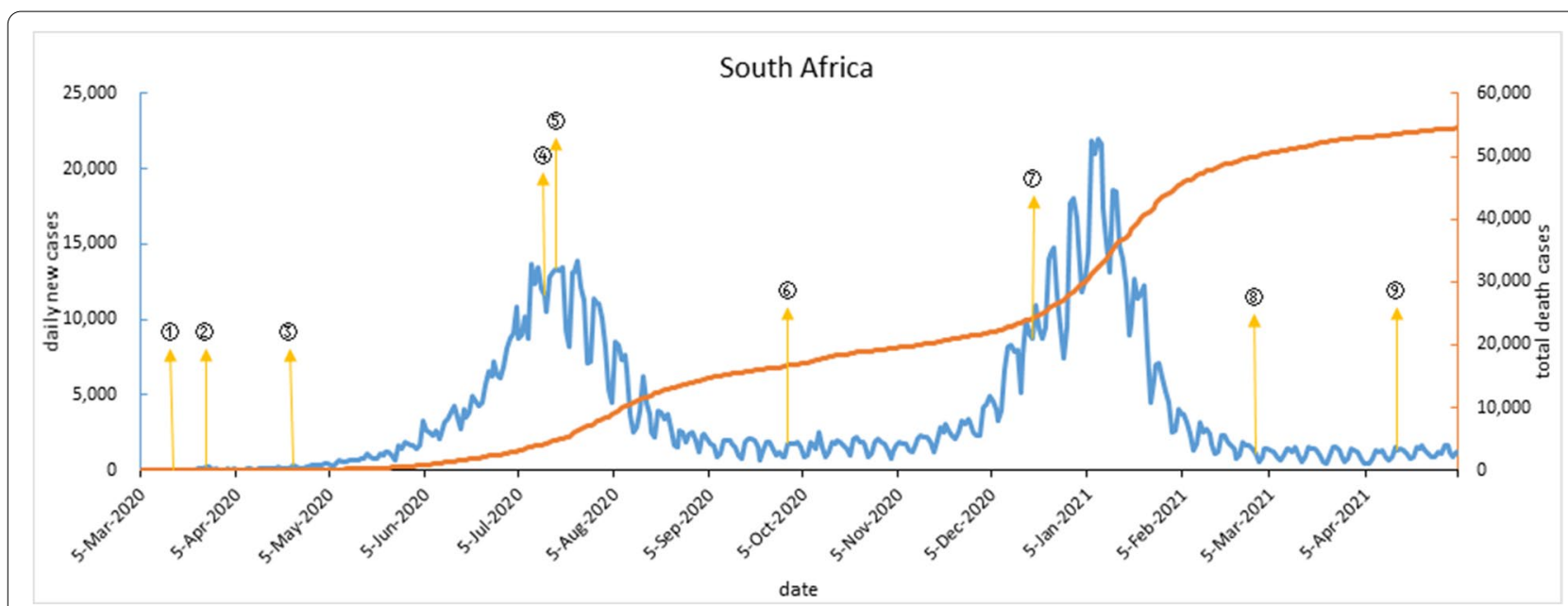

Fig. 3 COVID-19 outbreak curve and timeline of implementation of major interventions in South Africa. Note: (1) On March 15, 2020, suspended visa issuance to visitors from high-risk countries; Closed 35 land ports and 2 waterways; Strengthened airport monitoring measures. (2) At midnight on March 26, South Africa began a 21-day "lockdown", and the lockdown level was set as Level 5, the strictest. (3) From April 23, gradually relaxed the level of lockdown order and allowed enterprises to resume work. (4) On July 13, a curfew was imposed from 14 to 4, alcohol bans were reintroduced and masks were required. (5) On July 17, 5,571 isolation sites were set up across the country. (6) On Oct 1, all bans on COVID-19 were fully lifted, borders were reopened and international travel resumed. (7) On Dec 18, the "lockdown" was upgraded from Level 1 to Level 3, and curfews, masks and alcohol bans were reinstated. (8) On Feb 28, 2021, upgraded the lockdown to Level 1, shortened curfews, permitted the sale of alcohol, and certain gatherings were allowed with conditions. (9) On April 16, electronic registration for the COVID-19 vaccine was opened to all

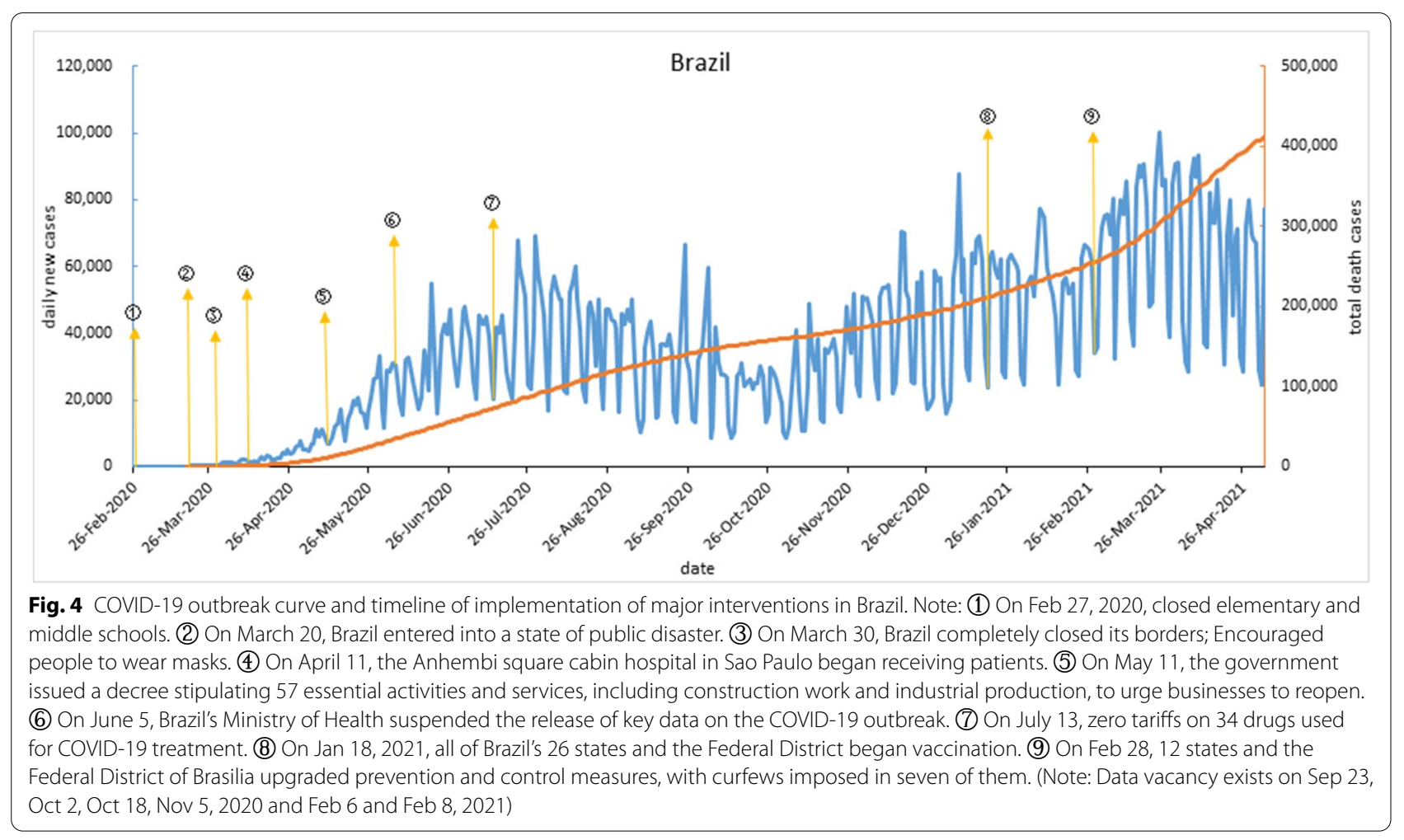


shows a cyclical trend of five days increasing and two days decreasing, which coincides with Brazilian rest days. As shown in Fig. 4.

On Jan 31, 2020, after two confirmed cases, Russia immediately closed border and successfully controlled import cases. In mid-Mar, confirmed cases began to rapidly increase. On May 3, 2020, daily new cases exceeded 10,000. On May 11, 2020, national paid vacation ended and restrictions were lifted in stages, with daily new cases a steady drop. On Sep 1, 2020, Russian schools opened, and daily new cases rebounded, with the second wave beginning. Restrictions were introduced in late Oct 2020 and a nationwide vaccination was launched on Dec 4, 2020. The second wave peaked in Dec 2020 and gradually subsided, with daily new cases stabilizing to around 8,000 by May 2021. As shown in Fig. 5 .

\section{The total confirmed cases, total deaths, and total deaths per million in BRICS countries}

China's total confirmed cases have stabilized at 10,000, while India, Brazil, Russia, and South Africa have the highest confirmed cases in the world. Brazil's total deaths were higher than India which had 5.8 million more confirmed cases. Total deaths per million China remained at 3.37 lower than India at 163.90 , Russia at 751.50 , South Africa at 919.11, and Brazil at the highest of 1,936.34. As shown in Fig. 6.

\section{Discussion}

Based on the national health care system, population structure, and epidemic situations, BRICS countries took different interventions to combat COVID-19. China adhered to containment strategy, focusing on the whole transmission process; India and South Africa adopted intermediate strategies, taking different strategies at different epidemic stages; Brazil and Russia took mild mitigation strategies to ease pressure on health care systems.

Curitiba's Declaration highlighted equity as a prerequisite for health and as an essential element of health promotion [28]. Many countries are facing insufficient health costs, vulnerable groups difficulty accessing health care, and inequity factors between countries. These health inequity factors accelerate disease development, especially in COVID-19. International solidarity and cooperation in fighting pandemics, conducting active international exchanges and cooperation, and building a Global Community of Health for All are effective to contain the spread of COVID-19 pandemic.

\section{Containment strategies}

China's prevention and control effect shows that containment strategies can have a positive impact on limiting the spread of COVID-19 [19]. Containment strategies focus on strict prevention and control of the Coronavirus transmission process, which requires extensive funding

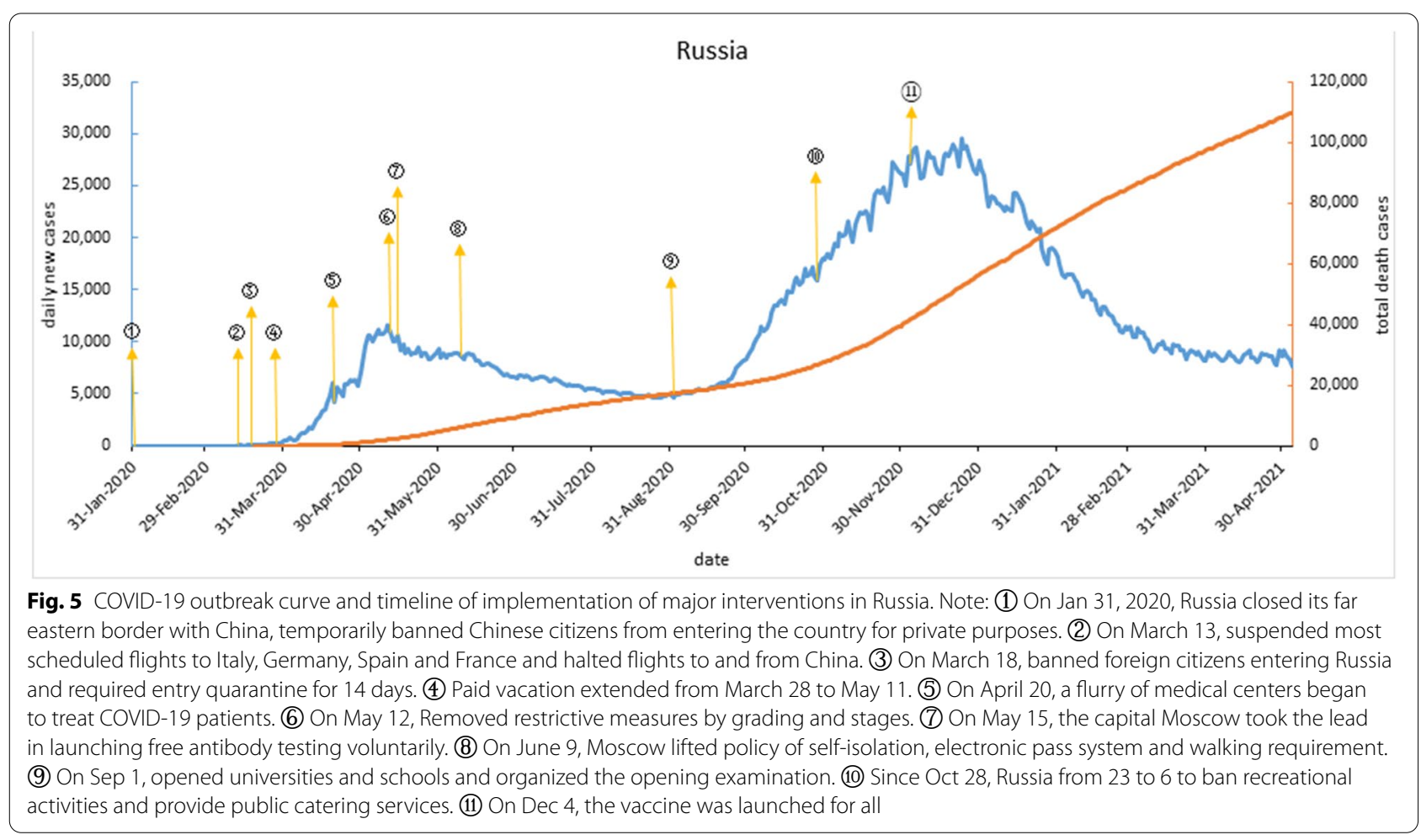




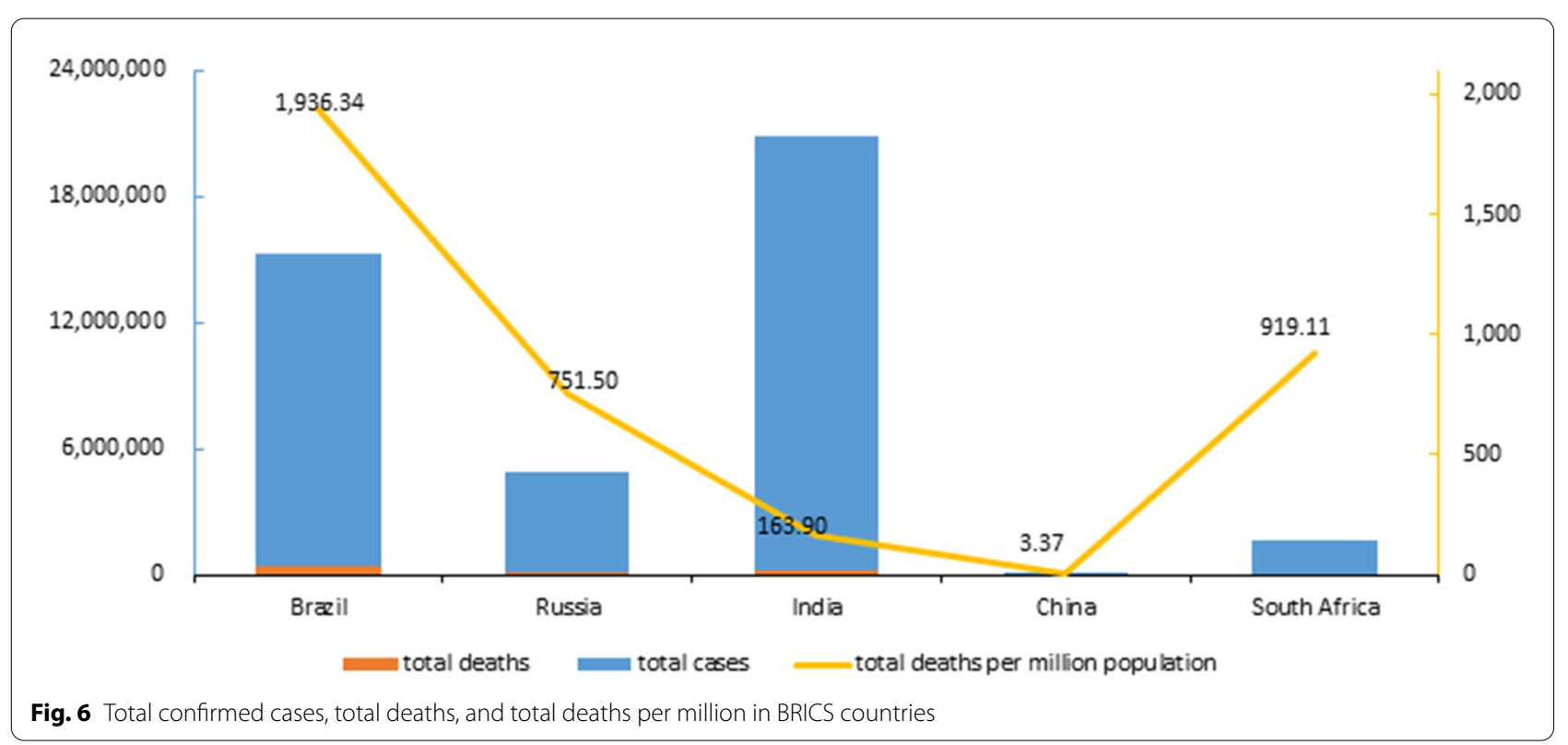

to support nucleic acid testing, medical treatment, and close contact screening. The Current health expenditure per capita in China in 2018 was only US\$501.06 [29], less than half of the world average. However, China covered all costs of COVID-19 treatment, which was about US $\$ 3,542$ for a confirmed patient [26]. In addition, all COVID-19 treating drugs were included in medical insurance, ensuring equitable access to medical treatment. China adheres to the principle of all those in need are treated, which reflects adherence to the supremacy of the people and life.

At the early stage, China carried out several epidemiological investigations and lockdown Wuhan city to limit the rapid spread of COVID-19 epidemic, and closely tracked and managed the "four categories of people". Facing surge medical demand contradicted the lack of medical resources, China established cabin hospitals, organized pairing assistance from provinces to cities, and so on. Public ownership of hospitals and a philosophy of support from all sides when one side is in trouble ensured these measures' implementation. For imported cases, the first point of entry and closed-loop management were implemented to reduce harm. Although in the normalized stage of epidemic prevention and control, there have been several clusters and sporadic cases, China has actively carried out epidemiological investigations and traced the source of confirmed cases, searched for close contacts, and delineated the risk level and control area scientifically and accurately, and all cluster cases have been effectively controlled.

Lockdown measures are a key part of containment strategies and are mostly implemented in early stages and large clusters. China, India, and South Africa all imposed lockdown measures, which effectively slowed virus spread. Early lockdown measures can slow down large-scale outbreaks, reduce cross-infection, and facilitate screening of patients. It could also reduce the burden on the health system.

\section{Intermediate strategies}

The intermediate strategy is choosing containment strategy or mitigation strategy at different stages. And intermediate strategies are preferred in many less developed countries and countries with few medical resources. In general, Containment strategies were implemented in the early stages to prevent and control the epidemic, then implemented mitigation strategies were to safeguard the normal conduct of productive life. However, the timing of choosing to implement mitigation strategies needs to be scientifically determined based on the country's situation.

India and South Africa both adopted containment strategies in the early stages of the domestic outbreak. Between Mar and June 2020, India implemented a fivestage blockade, with a ban on domestic and international travel, and daily new cases increased slowly. However, India's poor account for $9.7 \%$, they concentrate in slums, small living areas, densely populated populations [30], which can't reach conditions for home isolation, coronavirus was rapidly spreading among the poor. In the first blockade, India implemented policies of closing factories and public transportation, which lacked attention to workers and led to many people returning home on foot, increasing movement and virus spread. Resumed work 
and production without the epidemic being controlled, the second wave has become more and more intense with the help of coronavirus variant. Affected by the mass gathering of religious activities and inadequate epidemic education, knowledge and implementation of COVID19 prevention and control measures are not in place. In addition, India's Current health expenditure per capita in 2018 was only US $\$ 72.83$ [29], with inadequate primary health care and public health system [31, 32], inability to guarantee basic health equity. As for the low total deaths per million in India, the government recognized the lack of health resources, in the spreading stage implemented a five-stage blockade and handwashing with soap [31], effectively containing the outbreak. In addition, India is the 2nd largest populous country and the population structure is young with fewer basic diseases, which is strongly immune to the virus [33].

Thanks to the 21-day nationwide lockdown and preceded border closures, the curve of daily new cases in South Africa was demonstrably flattening [34], with the infection rate dropping to 4 percent. These measures delayed the epidemic peak and won time to prepare medical supplies and organize staff. Infectious disease is a major problem impacting the health of African people [35]. In COVID-19 close contact tracing and management, South Africa organized 10,000 members of Tuberculosis control teams to undertake the work. Unlike in containment strategy that implements nonessential not go out, South Africa lockdown measure still allowed social gatherings below 100 people which led to several funeral-gathering infections. Even so, unemployment still hit $30.1 \%$, making the stop-production measures unsustainable. South Africa prematurely lifted the blockade and resumed production, which led to a surge of infected people and a second epidemic wave, which is consistent with the findings of American scholar Richard [36] that early withdrawal of interventions will lead to a rebound or resurgence of the epidemic. Refugees, international asylum-seekers, and undocumented migrants were excluded from policies and COVID-19 brought a disproportionate impact on them [37]. South Africa's Current health expenditure per capita in 2018 was US\$525.96 at a low level [29], which is another reason for the high death rate.

Resuming work is an urgent need, but a key reason for many countries' COVID-19 rebound. It is also a turning point of intermediate strategy. When COVID-19 was not stabilized, both India and South Africa resumed work, and relaxed social restrictions, leading to the second wave. Therefore, it is important to choose the time to implement resumption of work policy according to the realities in their countries, as well as prevention and control policies such as social distancing, wearing masks, and personnel management.

\section{Mitigation strategies}

Mitigation strategies focus on close contact tracing and critically patient treatment, supplemented by slight social restrictions and blockade. The goal is to keep COVID-19 slow spread and smooth epidemic peaks under maintaining a normal life.

Brazil's federal and local governments were divided in responding to COVID-19. The federal government kept passive response and the leader believed that prevention measures must be carried out under normal production activities [38]. They only advocated wearing masks and closing schools. Rapid data sharing is the basis for control measures' development and implementation during epidemic [39], but Brazil's key epidemic data was suspended several times. Brazilian President Bolsonaro's "passive response" was considered the biggest threat to COVID-19 [40]. Local governments made the main community-based measures, which caused a wide variation in measures across the country. Brazil's medical system is based on universal free medical care, but faces poor infrastructure, a large gap of wealth, and a shortage of prevention materials. Like India, Brazil has many slums where the poor live on transient incomes, making it difficult to maintain long-term home isolation. Furthermore, due to mutated viruses, Brazil's both Current health expenditure per capita and rate of deaths per million people were the highest among BRICS countries. Especially among the poor, more than half of deaths occurred in the intensive care units of public hospitals.

Russia advocated "mild epidemic prevention", which was seeking a middle way between lockdown city and complete lifting of restrictions. In fact, Russia adopted typical mitigation strategies. Even during "quasi-lockdown city" with national paid vacation, gatherings to 5,000 people were restricted, and wearing masks mandatory began in May 2020. A Russian study concluded that a comprehensive blockade of marginal effect would have less than restrictions on food, drink, and public gatherings [41]. Until the second wave, the medical community and government agreed that strict restrictive measures were unnecessary, and COVID-19 in Russia was controllable. However, the epidemic grew to a high level. Russia is located on the Eurasian continent and connected to the Worst-hit areas at the early stage of COVID-19. Russia is a vast territory with a sparse population, and its population and economy are concentrated in the European part. COVID-19 also showed huge spatial disparities, with similar regional distributions of infections and 
GDP per capita. Russia followed universal health care in Soviet with a capable health system capacity, learned about Chinese and Italian experiences, established multiple application mobile cabin hospitals, and organized mass nucleic acid testing. These measures detected early cases, timely carried out medical treatments and kept a relatively low death rate.

Carrying out vaccination is important for both containment and mitigation strategies to establish an immune barrier. Vaccines are an important tool to help protect people against viruses and reduce disease severity. In mitigation strategies, it and population-controlled infection work together to establish an immune barrier. Compared with other countries' efforts to develop, produce and acquire COVID-19 vaccines, Brazil did not actively carry out vaccine research and refused to accept COVID-19 vaccine assistance from Russia and China in the early stage.

\section{Health equity in BRICS}

Health inequity accelerates COVID-19 spread. Meanwhile, COVID-19 got our attention on health equity, and we face an extraordinary opportunity to advance health equity. As "Buckets Effect" shows: water produced in a bucket depends on the shortest plank. A country's epidemic control effectiveness depends on the weakest prevention and control measure. The world pandemic control effectiveness depends on the worst-affected country. Health equity in BRICS countries includes two aspects: health equity within countries, and health equity among BRICS countries.

According to the World Bank, Current health expenditure per capita in BRICS countries was below the world average of US\$1,111.08 [29], and a few rich people used most medical services. It is urgent to improve the primary health care system and increase health care equity. Coronavirus is mainly spread by droplet transmission [42], which is accelerated in congregating populations and living conditions with unsafe social distances such as slums and prisons. With a high proportion of poor people in BRICS countries, the ability to guarantee health equity for medically vulnerable populations affects COVID-19 control [43].

Making intervention policies more inclusive and incorporating health equity practices into all intervention measures can improve health equity and fight the epidemic successfully. For example, South Africa's single-room policy provided temporary shelters for homeless people and self-isolation places with unused houses and low investment, and China used government finance to cover all costs of COVID-19 treatment when the current health expenditure per capita was at a low level. Two examples use policy and government finance to fill shortcomings of epidemic prevention and control.

It is significant to keep health equity between countries in a worldwide pandemic that would damage health, economic and social development. Health inequity among BRICS countries is impacted by "vaccine nationalism" that banning exports of vaccines and key materials, artificial creating "immunization gap", politicizing the pandemic that blaming other countries for COVID-19 [8], restricting the export of medical supplies, and so on. These policies negatively affected health equity, cooperation, and mutual trust among BRICS countries in fighting COVID-19 which are not conducive to stem the worldwide pandemic.

\section{Epidemic cooperation in BRICS}

The COVID-19 prevention and control of the pandemic is not a matter of a single country. Virus knows no border, humans are a community of destiny, countries in the world are closely linked and interconnected. Only when the global pandemic is effectively controlled can they protect themselves, which requires international epidemic cooperation to achieve effective COVID-19 control. Foreign policy offers a means to achieve health equity and better health [44].

COVID-19 outbreak intensified international health cooperation: send medical experts, provided medical supplies, shared experience in fighting COVID19. Health cooperation provides material support for COVID-19 prevention and control. Personal protective equipment and medical equipment effectively reduced the infection rate of health workers and the death rate of COVID-19 patients. Vaccine cooperation led by countries that own vaccines, including vaccine research, development, production, distribution, and donation has contributed to promoting vaccine equity, reducing infection and morbidity rates, and realizing herd immunity at an early date.

However, there are still some problems with BRICS cooperation. First, BRICS is a partnership, which is not binding on the actual behavior of each country; secondly, COVID-19 has caused obstacles to political trust and economic exchanges; moreover, each country has different COVID-19 response strategies, needs of medical resources and international cooperation.

Cooperation is the right choice to promote health equity and cope COVID-19 outbreak. In cooperation, BRICS countries should discard prejudice and seek common ground while reserving differences. Furthermore, BRICS Strategic Partnership should not only stay in exchanges and consensus. It should take concrete actions and produce concrete results to work together against 
the COVID-19 pandemic. BRICS countries continue to deepen epidemic cooperation under mutual trust and public health challenges, abandon the "nationalism" vaccine, promote to build the BRICS health community and a Global Community of Health for All [45].

\section{Conclusion}

BRICS countries have implemented different interventions to limit the spread of coronavirus. China adopted containment strategy, South Africa and India adopted intermediate strategy combining containment strategy with mitigation strategy, and Brazil and Russia adopted mitigation strategy. The number of daily new cases in China is lower than in the other four countries. These results suggest that containment strategies are more effective than intermediate and mitigation strategies in limiting the spread of COVID-19. Especially when strict containment strategies are implemented early in the outbreak, but premature relaxation of restrictions may lead to a rebound and accelerated the spread of COVID-19. It is a good choice to combat COVID-19 by improving the inclusiveness of intervention policies, deepening BRICS epidemic cooperation, and increasing health equities.

\section{Acknowledgments}

The authors gratefully acknowledge the financial supports by the Natural Science Foundation of Guangdong Province in 2022: Construction and application of COVID-19 control model PSR-SOR-Haddon in Guangdong Province; the National Social Science Fund of China (No. 16BGL184).

\begin{abstract}
Authors' contributions
JJ and GS conceived the paper. YZ, HC, XW, MY, JY, and ML collected the data. JJ drafted the manuscript. $L S, H C$, and $X W$ revised the manuscript. GS contributed to the critical revision of the manuscript for important intellectual content and approved the final version of the manuscript. All authors have read and approved the final manuscript. JJ and GS are the study guarantors.
\end{abstract}

\section{Funding}

This study was supported by the Natural Science Foundation of Guangdong Province in 2022: Construction and application of COVID-19 control model PSR-SOR-Haddon in Guangdong Province; The National Social Science Fund of China (No. 16BGL184).

\section{Availability of data and materials}

The datasets analyzed during the current study are available in the Johns Hopkins Coronavirus Resource Center repository, [https://coronavirus.jhu. edu/]; World Health Organization, [https://www.who.int/data\#dashboards]; and National Health Commission, PRC [http://www.nhc.gov.cn/xcs/yqtb/list gzbd.shtml (Webpage in Chinese)].

\section{Declarations}

Ethics approval and consent to participate

This study did not involve ethical issues.

\section{Consent for publication}

Not applicable.

\section{Competing interests}

The authors have no conflicts of interest to declare.

\section{Author details}

${ }^{1}$ Department of Health Management, School of Health Management, Southern Medical University, Guangzhou, Guangdong 510515, P.R. China. ${ }^{2}$ Department of Health Policy and Management, Bloomberg School of Public Health, Johns Hopkins University, Baltimore, MD 21205, USA.

Received: 11 August 2021 Accepted: 27 December 2021

Published online: 20 January 2022

References

1. Hui DS, Azhar IE, Madani TA, et al. The continuing 2019-nCoV epidemic threat of novel coronaviruses to global health - The latest 2019 novel coronavirus outbreak in Wuhan, China. Int J Infect Dis. 2020;91:264-6. https://doi.org/10.1016/j.ijid.2020.01.009.

2. WHO Director-General's remarks at the media briefing on 2019-nCoV on 11 February 2020. https://www.who.int/zh/director-general/speeches/ detail/who-director-general-s-remarks-at-the-media-briefing-on-2019ncov-on-11-february-2020. Published 11 Feb 2020.

3. Anderson RM, Vegvari C, Truscott J, Collyer BS. Challenges in creating herd immunity to SARS-CoV-2 infection by mass vaccination. Lancet Lond Engl. 2020;396(10263):1614-6. https://doi.org/10.1016/S01406736(20)32318-7.

4. Genomic epidemiology of novel coronavirus - global subsampling. https://nextstrain.org/ncov/global?dmax=2021-05-04.

5. Aleem A, Akbar Samad AB, Slenker AK. Emerging variants of SARS-CoV-2 and novel therapeutics against coronavirus (COVID-19). In: StatPearls. Treasure Island (FL): StatPearls Publishing; 2021. http://www.ncbi.nlm.nih. gov/books/NBK570580/. Accessed 10 Jun 2021.

6. Cucinotta D, Vanelli M. WHO declares COVID-19 a pandemic. Acta Bio Med Atenei Parm. 2020;91(1):157-60. https://doi.org/10.23750/abm. v91i1.9397.

7. Harmer A, Xiao Y, Missoni E, Tediosi F. "BRICS without straw"? A systematic literature review of newly emerging economies' influence in global health. Glob Health. 2013;9:15. https://doi.org/10.1186/1744-8603-9-15.

8. Chen S, Xiujun X. BRICS cooperation in the face of COVID-19: challenges, opportunities and responses. Contemp World. 2020;(12):65-72. https:// doi.org/10.19422/j.cnki.ddsj.2020.12.010.

9. World Health Organization. WHO global influenza preparedness plan. https://www.who.int/csr/resources/publications/influenza/WHO_CDS_ CSR_GIP_2005_5.pdf. Accessed 1 Nov 2021.

10. World Health Organization. Transcript of the Press Conference undertaken with Dr Keiji Fukuda, Assistant Director-General ad. Interim for Health Security and Environment World Health Organization 26 April 2009The first thing is that we will be giving regular meeting with the press on a daily basis and this is the first of those meetings. :13.

11. Chen W, Wang Q, Li YQ, et al. Early containment strategies and core measures for prevention and control of novel coronavirus pneumonia in China. Zhonghua Yu Fang Yi Xue Za Zhi. 2020;54(3):239-44. https://doi. org/10.3760/cma.j.issn.0253-9624.2020.03.003.

12. Ye Y. Analysis of influenza epidemic and control strategy. Endem Dis Bull. 2008;23(03):69-70. https://doi.org/10.13215/j.cnki.jbyfkztb.2008.03.031.

13. Nicoll A, Coulombier D. Europe's initial experience with pandemic (H1N1) 2009 - mitigation and delaying policies and practices. Euro Surveill Bull Eur Sur Mal Transm Eur Commun Dis Bull. 2009;14(29):19279. https://doi. org/10.2807/ese.14.29.19279-en.

14. Chen YH, Fang CT. Mortality from COVID-19: a cross-country comparison of containment versus mitigation strategy. J Formos Med Assoc. 2020;119(11):1710-2. https://doi.org/10.1016/j.jma.2020.05.029.

15. Vo HL, Nguyen HAS, Nguyen KN, et al. Adherence to social distancing measures for controlling COVID-19 pandemic: successful lesson from Vietnam. Front Public Health. 2020;8:589900. https://doi.org/10.3389/ fpubh.2020.589900.

16. Wang $X$, Shi L, Zhang Y, Chen H, Sun G. Policy disparities in fighting COVID-19 among Japan, Italy, Singapore and China. Int J Equity Health. 2021;20(1):33. https://doi.org/10.1186/s12939-020-01374-2.

17. Oh HS, Woong S. Strict containment strategy and rigid social distancing successfully contained COVID-19 in the military in South Korea. Mil Med. 2020;185(11-12):476-9. https://doi.org/10.1093/milmed/usaa211. 
18. Son $\mathrm{H}$, Lee $\mathrm{H}$, Lee $\mathrm{M}$, et al. Epidemiological characteristics of and containment measures for COVID-19 in Busan, Korea. Epidemiol Health. 2020;42:e2020035. https://doi.org/10.4178/epih.e2020035.

19. Caristia S, Ferranti M, Skrami E, et al. Effect of national and local lockdowns on the control of COVID-19 pandemic: a rapid review. Epidemiol Prev. 2020;44(5-6 Suppl 2):60-8. https://doi.org/10.19191/EP20.5-6.S2.104.

20. Ferguson NM, Cummings DAT, Fraser C, Cajka JC, Cooley PC, Burke DS. Strategies for mitigating an influenza pandemic. Nature. 2006:442(7101):448-52. https://doi.org/10.1038/nature04795.

21. Lee DH, Shin SS, Jun BY, Lee JK. National level response to pandemic (H1N1) 2009. J Prev Med Pub Health. 2010;43(2):99-104.

22. Kim S, Castro MC. Spatiotemporal pattern of COVID-19 and government response in South Korea (as of May 31, 2020). Int J Infect Dis. 2020;98:328-33. https://doi.org/10.1016/j.ijid.2020.07.004.

23. Peirlinck M, Linka K, Costabal FS, et al. Visualizing the Invisible: The Effect Of Asymptomatic Transmission On The Outbreak Dynamics of COVID-19; 2020. https://doi.org/10.1101/2020.05.23.20111419.

24. Regmi K, Lwin CM. Factors associated with the implementation of non-pharmaceutical interventions for reducing coronavirus disease 2019 (COVID-19): a systematic review. Int J Environ Res Public Health. 2021;18(8):4274. https://doi.org/10.3390/ijerph18084274.

25. Cowling BJ, Ali ST, Ng TWY, et al. Impact assessment of non-pharmaceutical interventions against coronavirus disease 2019 and influenza in Hong Kong: an observational study. Lancet Public Health. 2020;5(5):e279-88. https://doi.org/10.1016/S2468-2667(20)30090-6.

26. Fighting Covid-19: China in action - Chinadaily.com.cn. https://epaper. chinadaily.com.cn/a/202006/08/WS5edd76f5a3107831ec752924.html. Accessed 23 Aug 2021.

27. Liu H, Wei P, Zhang Q, et al. 501Y.V2 and 501Y.V3 variants of SARS-CoV-2 lose binding to bamlanivimab in vitro. mAbs. 2021;13(1):1919285. https:// doi.org/10.1080/19420862.2021.1919285.

28. de Amorim AC, Fernandes VR, Sérgio JV, Vicente da Silva JP. Health and equity in Latin America: utopias and reality. Health Promot Int. 2019;34(Supplement_1):i11-9. https://doi.org/10.1093/heapro/daz014.

29. Current health expenditure per capita (current US\$) | Data. https://data. worldbank.org/indicator/SH.XPD.CHEX.PC.CD?end=2018\&most_recent_ value_desc $=$ true\&start=2018\&view=map. Accessed 19 Aug 2021.

30. Choudhari R. COVID 19 pandemic: mental health challenges of internal migrant workers of India. Asian J Psychiatry. 2020;54:102254. https://doi. org/10.1016/j.ajp.2020.102254.

31. Paital B, Das K, Parida SK. Inter nation social lockdown versus medical care against COVID-19, a mild environmental insight with special reference to India. Sci Total Environ. 2020;728:138914. https://doi.org/10.1016/j.scito tenv.2020.138914

32. Naidoo $D$, Schembri $A$, Cohen $M$. The health impact of residential retreats: a systematic review. BMC Complement Altern Med. 2018;18(1):8. https:// doi.org/10.1186/s12906-017-2078-4.

33. Elrashdy F, Redwan EM, Uversky VN. Why COVID-19 transmission is more efficient and aggressive than viral transmission in previous coronavirus epidemics? Biomolecules. 2020;10(9):1312. https://doi.org/10.3390/ biom10091312.

34. There is reason to be hopeful, Mkhize says - SA Corona virus online portal. SA Corona Virus Online Portal. 2020. https://sacoronavirus.co.za/2020/07/ 31/there-is-reason-to-be-hopeful-mkhize-says/. Accessed 10 Jun 2021.

35. Chen Y, Han L, Liu C. Current status of surveillance for infectious diseases in Africa. Zhonghua Liu Xing Bing Xue Za Zhi. 2018;39(11):1530-4. https://doi.org/10.3760/cma.j.issn.0254-6450.2018.11.021.

36. Hatchett RJ, Mecher CE, Lipsitch M. Public health interventions and epidemic intensity during the 1918 influenza pandemic. Proc Natl Acad Sci U S A. 2007;104(18):7582-7. https://doi.org/10.1073/pnas.0610941104.

37. Mukumbang FC, Ambe AN, Adebiyi BO. Unspoken inequality: how COVID-19 has exacerbated existing vulnerabilities of asylum-seekers, refugees, and undocumented migrants in South Africa. Int J Equity Health. 2020;19:141. https://doi.org/10.1186/s12939-020-01259-4.

38. The Lancet. COVID-19 in Brazil: "So what?". Lancet Lond Engl. 2020:395(10235):1461. https://doi.org/10.1016/S0140-6736(20)31095-3.

39. Sabino EC, Buss LF, Carvalho MPS, et al. Resurgence of COVID-19 in Manaus, Brazil, despite high seroprevalence. Lancet Lond Engl. 2021;397(10273):452-5. https://doi.org/10.1016/S0140-6736(21)00183-5.

40. Hallal PC, Hartwig FP, Horta BL, et al. SARS-CoV-2 antibody prevalence in Brazil: results from two successive nationwide serological household surveys. Lancet Glob Health. 2020;8(11):e1390-8. https://doi.org/10.1016/ S2214-109X(20)30387-9.

41. Brauner JM, Mindermann S, Sharma M, et al. Inferring the effectiveness of government interventions against COVID-19. Science. 2021;371(6531):eabd9338. https://doi.org/10.1126/science.abd9338.

42. Liu Y, Qu HQ, Qu J, Tian L, Hakonarson H. Expression pattern of the SARSCoV-2 entry genes ACE2 and TMPRSS2 in the respiratory tract. Viruses. 2020;12(10):E1174. https://doi.org/10.3390/v12101174.

43. Telenti A, Arvin A, Corey L, et al. After the pandemic: perspectives on the future trajectory of COVID-19. Nature. 2021;596(7873):495-504. https:// doi.org/10.1038/s41586-021-03792-w.

44. Kevany S, Gildea A, Garae C, Moa S, Lautusi A. Global health diplomacy, national integration, and regional development through the monitoring and evaluation of HIV/AIDS programs in Papua New Guinea, Vanuatu, and Samoa. Int J Health Policy Manag. 2015;4(6):337-41. https://doi.org/10. 15171/ijhpm.2015.89.

45. Speech by Xi Jinping, President of the People's Republic of China, at the 12th BRICS Leaders' Meeting The State Council Bulletin No. 33 of 2020 - China.gov.cn. http://www.gov.cn/gongbao/content/2020/content_ 5565809.htm. Accessed 10 Jun 2021.

\section{Publisher's Note}

Springer Nature remains neutral with regard to jurisdictional claims in published maps and institutional affiliations.

Ready to submit your research? Choose BMC and benefit from:

- fast, convenient online submission

- thorough peer review by experienced researchers in your field

- rapid publication on acceptance

- support for research data, including large and complex data types

- gold Open Access which fosters wider collaboration and increased citations

- maximum visibility for your research: over 100M website views per year

At BMC, research is always in progress.

Learn more biomedcentral.com/submissions 